\title{
RANCANGAN SISTEM MANAJEMEN ANTI PENYUAPAN (ISO 37001:2016) BERBASIS MANAJEMEN RISIKO
}

\author{
Hermawan $^{1)^{*}}$, Aries Heru Prasetyo ${ }^{2)}$ \\ 1) hermawanhermawan1968@gmail.com, Sekolah Tinggi Manajemen PPM* \\ 2) justzhongshan@gmail.com, Sekolah Tinggi Manajemen PPM \\ *penulis korespondensi
}

\begin{abstract}
PT. Micro Madani Institute (MMI) is an affiliated company of PT. Permodalan Nasional Madani (Persero) which was formed to build and develop an education and training center in the field of microfinance in order to obtain reliable, professional and integrity human resources as well as to provide procurement, management, and development of quality human resources in the microfinance sector to support human resource needs of PT Permodalan Nasional Madani (Persero) as the parent company. The purpose of this research is to find out the risk profile that has been identified in building the Anti-Bribery Management System (SMAP) ISO 37001:2016, to find out what SMAP strategic design instruments have not been implemented, and how the SMAP process is based on risk management at PT. MMI during 2021. PT. MMI has adopted SMAP ISO 37001:2016 in April 2021 to increase consumer confidence and make employees more integrity in their work, as a company standard in the procurement of goods and services as well as good corporate governance standards. So far, PT. MMI has not found any bribery cases, but so far the company has not had a strategic plan to strengthen the implementation of the risk management-based SMAP (ISO 37001:2016). Implementation of risk management-based SMAP is considered necessary because the implementation of SMAP alone cannot fully guarantee that an organization is free from acts of bribery.
\end{abstract}

Keywords : Management System, Bribery, Risk Management

\begin{abstract}
Abstrak
PT. Micro Madani Institute (MMI) merupakan perusahaan afiliasi PT. Permodalan Nasional Madani (Persero) yang dibentuk untuk membangun dan mengembangkan pusat pendidikan dan pelatihan di bidang microfinance guna mendapatkan sumber daya manusia yang handal, profesional dan berintegritas serta menyediakan jasa layanan pengadaan, pengelolaan, dan pengembangan sumber daya manusia yang berkualitas di bidang microfinance guna mendukung kebutuhan sumber daya manusia PT. Permodalan Nasional Madani (Persero) sebagai perusahaan induknya. Tujuan penelitian ini adalah mengetahui profil risiko yang berhasil diidentifikasi dalam membangun Sistem Manajemen Anti Suap (SMAP) ISO 37001:2016, mengetahui apa saja instrumen rancangan strategis SMAP yang belum diimplementasikan, dan bagaimana proses SMAP berbasis manajemen risiko di PT. MMI selama tahun 2021. PT. MMI. telah mengadopsi SMAP ISO 37001:2016 pada April 2021 untuk meningkatkan kepercayaan konsumen dan menjadikan karyawan semakin berintegritas dalam setiap pekerjaannya, sebagai standar perusahaan dalam pengadaaan barang dan jasa serta standar tata kelola perusahaan (good corporate governance). Sejauh ini, PT. MMI belum menemukan kasus penyuapan, namun sejauh itu pula perusahaan belum memiliki rancangan strategis untuk memperkuat implementasi SMAP (ISO 37001:2016) berbasis manajemen risiko yang baru diadposinya. Pelaksanaan SMAP berbasis manajemen risiko dianggap perlu karena penerapan SMAP saja tidak dapat sepenuhnya menjamin suatu organisasi terbebas dari tindak penyuapan.
\end{abstract}

Kata Kunci : Sistem Manajemen, Penyuapan, Manajemen Risiko

\section{PENDAHULUAN}

Sistem Manajemen Anti Suap (SMAP) diterbitkan oleh salah satu lembaga internasional yang bergerak dibidang pengelolaan standarisasi sistem manajemen bidang industrial dan komersial, yaitu ISO (International Organization for Standardization). SMAP atau ISO 37001:2016 memberikan panduan kepada organisasi baik disektor publik, swasta maupun nirlaba untuk mencegah upaya penyuapan. Indonesia telah menjadi aggota ISO sejak 1965. Penerapan ISO 37001:2016 di Indonesia diserahkan kepada lembaga Badan Standarisasi Nasional (BSN) yang kemudian nilai ini dijadikan standar komitmen kepemimpinan.

SMAP lahir dari kebutuhan penanganan perilaku suap yang sudah dianggap menjadi masalah serius dan berbahaya (Tabel 1). Lebih dari 50\% kasus terbesar yang ditangani Komisi Pemberantasan Korupsi (KPK) dari tahun 2004 hingga 2019 adalah kasus suap (Mapuasari \& 
Hadi, 2018). Kasus ini melibatkan berbagai profesi, yaitu pejabat eselon (22\%), pengusaha swasta (25\%), wakil rakyat pusat dan daerah (20\%), dan selebihnya adalah komisioner, gubenur, bupati, walikota, dan profesi lain (Prabowo \& Suhernita, 2018). Kasus suap telah mengakibatkan: (1) lemahnya kepemimpinan; (2) lemahnya kebijakan yang diambil; dan (3) rendahnya kinerja birokrasi. Ketiga hal ini menciptakan inefisiensi, lambatnya pertumbuhan suatu lembaga, memperburuk citra dan iklim investasi (Andreas, 2017).

Tabel 1. Tindak Pidana Korupsi Menurut Jenis Perkara (2004 - 2019)

\begin{tabular}{lrr}
\hline $\begin{array}{c}\text { JENIS PERKARA TINDAK } \\
\text { PIDANA KORUPSI }\end{array}$ & JUMLAH KASUS & PERSENTASE \\
\hline Penyuapan & 661 & $65,6 \%$ \\
\hline Pengadaan Barang/Jasa & 205 & $20,4 \%$ \\
\hline Penyalahgunaan Anggaran & 48 & $4,8 \%$ \\
\hline Pencucian Uang & 34 & $3,4 \%$ \\
\hline Pungutan & 26 & $2,6 \%$ \\
\hline Perijinan & 23 & $2,3 \%$ \\
\hline Merintangi Proses KPK & 10 & $1,0 \%$ \\
\hline Total Perkara & $\mathbf{1 . 0 0 7}$ & $\mathbf{1 0 0 , 0 \%}$ \\
\hline
\end{tabular}

Sumber: Mapuasari \& Hadi (2019)

SMAP adalah sistem manajemen yang dianggap terbaik dan dijadikan standar internasional untuk (1) mengantisipasi praktek suap; (2) menerapkan sistem komunikasi yang mewajibkan semua orang dalam suatu organisasi paham standard operating procedure SMAP; (3) terlaksananya kompetisi yang sehat dan objektif; (4) memposisikan pemimpin sebagai role model pribadi yang berintegritas dan professional (Lukiawan, 2018; Fasa \& Sani, 2020). Pelaksanaan SMAP perlu berbasis manajemen risiko karena penerapan SMAP saja tidak dapat sepenuhnya menjamin suatu organisasi terbebas dari tindak penyuapan. Manajemen risiko membantu mengidentifikasikan risiko penyuapan dan mengambil langkah mitigasi yang tepat untuk mengendalikan risiko dalam rangka mencegah terjadinya penyuapan yang tidak diatur secara detail dalam SMAP. Manajemen risiko juga memperkuat SMAP untuk mengukur dampak atas penyimpangan yang terjadi yang dapat mengganggu tercapainya tujuan atau sasaran suatu organisasi.

Dari semua lembaga, baik swasta maupun pemerintah yang menggunakan SMAP berbasis manajemen risiko menyatakan manfaatnya sebagai berikut: (1) mencegah kecurangan; (2) jika terjadi kecurangan. Metode SMAP berbasis manajemen risiko mengharuskan adanya investigasi yang berujung pada pemberian sanksi; (3) manfaat dari SMAP berbasis manajemen risiko bukan saja berdampak kepada internal organisasi tetapi di dalam ekosistem bisnis yang terkait dengan organisasi pengguna (The Wolfsberg Group, 2017; Djoni et.al., 2020).

Penerapan SMAP berbasis manajemen risiko memerlukan rancangan strategis untuk mengimplementasikannya. Rancangan strategis yang dimaksud adalah kemampuan membuat alur prediksi, prosedur, metode dan analisis ilmiah untuk menentukan posisi organisasi dalam pencapaian tujuannya. Pada lembaga bisnis, kemampuan ini penting untuk membuat tahapan, mengimplementasikan tahapan dan mengevaluasinya. Secara keseluruhan penerapan SMAP berbasis manajemen risiko meliputi pembentukan, implementasi, operasional, pemeliharaan dan peningkatan berkelanjutan atas pencapaian strategis yang saling berhubungan dan berinteraksi.

PT. Micro Madani Institute (MMI) adalah perusahaan afiliasi dari PT. PNM (Persero) melalui penempatan modal anak perusahannya PNM Venture Capital dan PT Mitra Utama Madani. Perusahaan ini berdiri sejak tanggal 24 Maret 2015. Sebagai perusahaan yang bergerak 
dibidang jasa, tentunya sangat mudah bagi para pelaku di dalam menawarkan jasa menggunakan praktik-praktik gratifikasi atau penyuapan. Jika tidak segera diantisipasi, akibat dari kejadian tersebut tentu akan mencoreng nama baik perusahaan dan menghilangkan kepercayaan para pelanggan.

Penelitian sebelumnya menyebutkan bahwa SMAP merupakan instrumen penting yang dapat mendukung pencegahan penyuapan, disamping hanya bertumpu pada usaha penegakan hukum (Fasa \& Sani, 2020). Lukiawan (2018) telah meneliti tingkat kesiapan organisasiorganisasi tertentu di Palembang dan Yogyakarta dalam menerapkan SMAP, dimana diperoleh hasil penilaian yang bervariasi, mulai pada level preliminary hingga ready. Sementara itu, PT. MMI telah mengadopsi ISO 37001:2016 namun belum sepenuhnya memiliki rancangan strategis yang komprehensif untuk memperkuat implementasi SMAP (ISO 37001:2016). Temuan awal dari tinjauan umum atas rancangan strategis yang ada baru berada di tahap penyusunan SOP SMAP. Oleh karena itu, tujuan penelitian ini adalah mengidentifikasi profil risiko dalam membangun SMAP, mengidentifikasi instrumen rancangan strategis SMAP yang belum diimplementasikan, dan menganalisis proses SMAP berbasis manajemen risiko di PT. MMI, khususnya pada tahun 2021.

\section{KAJIAN PUSTAKA}

\section{Sistem Manajemen Anti Penyuapan (ISO 37001:2016)}

Korupsi terus terjadi dan merajalela di usia reformasi Indonesia yang ke 23 tahun sejak 1998. Merespon permasalahan tersebut, Pemerintah Pusat mengeluarkan Instruksi Presiden No. 10 Tahun 2016 tentang Aksi Pencegahan dan Pemberantasan Korupsi Tahun 2016 dan Tahun 2017 lalu. Salah satu rencana aksi yang ditekankan adalah mengembangkan Sertifikasi SMAP yang diamanatkan kepada Badan Standardisasi Nasional (BSN) sebagai penanggung jawab aksi inisiatif sertifikasi anti korupsi dengan target terselesaikannya standar internasional ISO 37001: 2016 untuk sektor swasta dan pemerintah diakhir tahun 2016.

Menurut Djoni et.al. (2020), SMAP adalah seperangkat elemen yang saling berhubungan dan berinteraksi dalam suatu organisasi untuk mengarahkan dan mengendalikan organisasi (menyusun, menetapkan dan menerapkan kebijakan, tujuan dan proses) sebagai tindakan untuk mencegah penyuapan. Adapun ISO 37001:2016 adalah standar persyaratan dan pedoman untuk membantu organisasi dalam mengimplementasikan anti suap atau meningkatkan pengendalian mengenai anti penyuapan yang sudah dimiliki oleh organisasi. Sistem Manajemen Anti Suap dengan standar ISO 37001:2016 diterbitkan oleh International Organization for Standardization (ISO) pada tahun 2016 dengan judul Anti Bribery Management System-Requirements With Guidance for Use. Selanjutnya, BSN mengimplementasikan standar tersebut menjadi SNI ISO 37001:2016 tentang Sistem Manajemen Anti Penyuapan. SMAP menggunakan pendekatan proses dengan metode PDCA : (1) Plan, menggambarkan apa yang hendak dicapai oleh organisasi; (2) Do, suatu proses untuk menerapkan apa yang sudah direncanakan sebelumnya; (3) Check, adalah proses evaluasi, memantau dan mengukur proses, hasil dan layanan yang dihasilkan terhadap kebijakan, tujuan, persyaratan, dan kegiatan yang direncanakan, dan melaporkan hasilnya; (4) Act, tindakan yang diambil untuk meningkatkan kinerja.

\section{Manajemen Risiko}

Manajemen risiko dapat diartikan pengelolaan risiko dalam suatu alur organisasi untuk menetapkan: (1) identifikasi risiko; (2) analisis/penilaian risiko; (3) monitoring risiko; dan (4) pelaporan dan pengendalian risiko (Nur et.al., 2012). Manajemen risiko ditujukan untuk memberikan arahan strategis dalam kerangka memahami nilai dan potensi yang dapat merugikan perusahaan. Memahami risiko juga mengandung pengertian terhadap kemampuan 
mendorong perusahaan untuk mengejar peluang dari risiko yang ada. Risiko memiliki keragaman tersendiri yang memerlukan pengelolaan dengan pendekatan yang luas. Bukan saja risiko yang bersifat operasional tetapi meliputi risiko dari keseluruhan bisnis, diantaranya risiko sistem, risiko diseputar nilai layanan pelanggan, risiko diseputar pemangku kepentingan dan risiko diseputar regulasi. Oleh karena itu manajemen risiko, selain memerlukan pendekatan yang luas juga perlu dikelola secara komprehensif, ketat dan sistematis (Robert, 2006).

Pengelolaan risiko membutuhkan keterlibatan dari seluruh elemen organisasi agar berjalan secara efisien. Fungsi manajemen risiko adalah untuk membentuk kerangka kerja maupun kerangka proses agar mampu menghadapi risiko-risiko signifikan yang dapat mempengaruhi pencapaian tujuan dan sasaran organisasi (Kusumah, 2001). Hal ini sejalan dengan apa yang didefinisikan oleh COSO, Enterprise Risk Management (ERM) bahwa manajemen risiko adalah proses integrasi strategi dan performance perusahaan dari mulai proses perencanaan hingga implementasi strategi (performance) perusahaan.

Selain dipandang negatif, risiko dipandang pula secara positif (Gilang et.al., 2015), karenanya tidak semua ahli sependapat bahwa risiko bersumber dari ketidakpastian. Ketidakpastian mencakup bagian yang lebih luas, sementara risiko hanya bagian dari "ketidakpastian". Keduanya dapat mengakibatkan dampak positif atau negatif terhadap proses bisnis, karenanya memerlukan pengelolaan yang tepat. Dalam cara berfikir konvensional dengan fokus kesejahteraan dan nilai maka risiko didefinisikan sebagai volatilitas dari outcome yang tidak diharapkan berdampak kepada assets, liabilities, equity, dan earnings. Dalam sudut pandang manajemen dan rekayasa, risiko merupakan konsep negatif dengan konotasi kegagalan (Ratih et.al., 2017).

Pengelolaan risiko menjadi penting untuk memberikan dampak positif terhadap kualitas layanan yang diharapkan dan memperkecil kerugian dalam ekosistem suatu organisasi. Implementasi pengelolaan risiko yang baik dapat meningkatkan nilai pada suatu organisasi sehingga memberikan profit. Secara umum, risiko dapat diklasifikasikan sebagai: (1) Risiko keuangan (leverage) yang akan memengaruhi keuntungan suatu usaha; (2) Risiko produk yang akan mempengaruhi operasional dan produk yang telah dihasilkan; (3) Risiko pasar adalah potensi yang bisa diprediksi jika terjadi sesuatu (Mudrika et.al., 2020). Oleh karena itu risiko mesti dikelola dalam suatu manajemen yang melibatkan proses, metode dan teknik yang membantu kepemimpinan memaksimalkan probabilitas dari event positif dan meminimalkan probabilitas dari event yang berlawanan (Lokobal et.al., 2014).

\section{METODE}

Penelitian ini bermaksud mengkaji penerapan ISO 37001:2016 SMAP berbasis manajemen risiko dengan pendekatan kualitatif di PT. MMI. Moleong (2013) menyebutkan bahwa penelitian kualitatif adalah penelitian dengan alur natural di dalam konteks tertentu dalam kehidupan. Peneliti berperan dan mengikuti alur tersebut dengan metode yang digunakan secara aktif untuk menganalisis persoalan bersama subjek penelitian.

Perspektif yang digunakan di dalam penelitian ini adalah paradigma konstruktifisme. Paradigma tersebut berpandangan realitas dalam organisasi dapat dimengerti dalam bentuk konstruksi mental yang bermacam-macam, berdasarkan penilaian sosial dan pengalaman didalam organisasi tersebut, dimana pertumbuhan dan dinamikanya tergantung kepada individu atau kelompok individu yang memiliki konstruksi mental. Konstruksi ini dapat berubah sesuai dengan realitasnya (Denzin et.al., 2009).

Penelitian dilaksanakan di PT. MMI dalam kurun waktu enam bulan, mulai dari bulan April hingga bulan Oktober 2021. Data primer dalam penelitian ini didapatkan dari wawancara mendalam dengan enam informan kunci yang terlibat secara aktif pada lingkungan atau 
kegiatan yang menjadi perhatian penelitian, bersedia dan mampu memberikan informasi tentang sesuatu yang ditanyakan oleh peneliti tanpa dipersiapkan terlebih dahulu. Data sekunder yang juga dijadikan rujukan meliputi dokumen-dokumen penerapan ISO 37001:2016 SMAP berbasis manajemen risiko di PT. MMI, peraturan dan perundangan yang menjadi dasar penerapan ISO 37001:2016 SMAP berbasis manajemen risiko, serta laporan dan foto-foto penerapan ISO 37001:2016 berbasis manajemen risiko SMAP di PT. MMI.

Analisis data dilakukan melalui tiga tahap. Pertama, seluruh data yang telah di dapat kemudian dipilih, diklasifikasi dan dikategorisasi berdasarkan kebutuhan tujuan analisis. Kedua, setelah data selesai direduksi kemudian disusun secara sistematis berdasarkan keperluan dan tujuan penelitian disertai dengan pilihan landasan teorinya menjadi narasi. Terakhir, sajian data yang objektif dan sistematis yang telah tersusun ditarik kesimpulan dengan mempertimbangkan kembali dokumentasi lapangan, knowledge sharing dan berbagai upaya yang dilakukan peneliti untuk mendapatkan temuan dan seperangkat data pembanding lainnya. Validasi penelitian sangat penting untuk diperhatikan sehingga perlu dilakukan beberapa hal, seperti memperpanjang pengamatan di lokasi penelitian, melakukan studi literatur, dan triangulasi (Pitoyo et.al., 2021).

\section{HASIL DAN PEMBAHASAN Implementasi SMAP ISO 37001:2016}

Metode SMAP dalam standar ISO 37001:2016 menggunakan pendekatan proses sebagai dasar pengembangan manajemen anti penyuapan yang dikorelasikan dengan aktifitas organisasi dan sumber daya manusia sebagai input yang diproses menjadi output. Efektifitasnya terletak pada pengelolaan sejumlah proses organisasi secara sistematis dan memberikan nilai tambah secara berkelanjutan melalui metode plan, do, check, act (PDCA). Proses ini diperhatikan dengan baik oleh PT. MMI untuk mendapatkan efektifitas pengelolaan manajemen anti penyuapan serta pencegahan dan penanggulangan risiko. Hingga penelitian ini diselesaikan, peneliti belum menemukan satu kasus suappun yang terjadi. Hanya ada satu keluhan pada bulan Maret 2021. Keluhan ini telah dicatat dalam logbook complaint dan sudah ditindaklanjuti. Indikasi ini menjelaskan bahwa secara konsepsional dan operasional PT. MMI telah mempersiapkan perencanaan, pelaksanaan dan evaluasi sistem ini dengan baik.

Sebelum mengadopsi SMAP ISO 37001:2016 berbasis manajemen risiko, PT. MMI telah proaktif menerapkan konsep-konsep manajemen anti penyuapan dari setiap jenis transaksi yang dilakukan, instrument bisnis, pengelolaan dan pengembangan sumber daya manusia, penggunaan teknologi, kerjasama dengan mitra usaha dan penyediaan produk. Metode anti penyuapan yang digunakan adalah menerapkan sistem penjaminan mutu secara internal terhadap pelanggan, kepemimpinan, proses bisnis, pengambilan kebijakan dan evaluasi. Untuk mencapai efektifitas pencapaian metode ini, PT. MMI melakukannya secara bertahap dan berkelanjutan, melibatkan seluruh divisi, bagian dan staf. Komitmen awal anti penyuapa dituangkan dalam penandatanganan bersama pencegahan anti fraud, gratifikasi dan penyuapan. 1) Plan

Manajemen risiko dipandang lebih progresif dalam mengidentifikasi eksposure berbagai macam risiko dan dianggap lebih efektif dalam mengelola serta menaggulangi berbagai risiko untuk menjaga kesinambungan proses bisnis. Penerapan manajemen risiko sebagai basis penerapan SMAP dianggap pula cukup baik untuk mengidentifikasi, mengukur, memantau, mengendalikan risiko pembiayaan, risiko operasional, risiko kemitraan, risiko kepatuhan, risiko reputasi dan lain sebagainya.

Perusahaan memandang bahwa penyuapan merupakan fenomena umum yang telah terjadi secara massif dan telah merusak diberbagai lembaga, baik di lembaga pemerintahan 
maupun non pemerintahan, karenanya penyuapan kemungkinan dapat juga terjadi di PT. MMI. Penyuapan adalah sebuah risiko. Risiko ini mesti diantisipasi agar tidak menimbulkan permasalahan serius terhadap tata kelola administrasi dan merusak kemampuan kompetisi perusahaan. Jika tidak terantisipasi dapat menimbulkan ketidakpastian, terjadinya inefisiensi, rendahnya kualitas kinerja dan produk yang dihasilkan serta hilangnya kepercayaan stakeholder. Pemahaman akibat penyuapan juga menjadi suatu hal yang direncanakan untuk disosialisasikan kepada seluruh personel perusahaan.

Proses perencanaan dimulai dengan membuat yuridiksi perusahaan yang menegaskan bahwa penyuapan merupakan pelanggaran yang memiliki konsekuensi serius terhadap perusahaan, karenanya tindak perilaku suap akan dituntut pertanggungjawabannya secara internal dan diselesaikan pula melalui jalur hukum yang berlaku. Kendati ada opsi penyelesaian melalui jalur hukum, Perusahaan membuat perencanaan secara menyeluruh dan memproritaskan pendekatan proaktif untuk mencegah praktek suap dalam bentuk pedoman anti penyuapan disetiap level dan fungsi disertai metode pencegahannya.

Pendekatan proaktif yang dilakukan, menempatkan level pimpinan sebagai pusat perhatian bagi seluruh personel, menjadi role model untuk mempraktekan kejujuran, transparansi, keterbukaan dan kepatuhan sebagai budaya perusahaan. Setelah pada level pimpinan mengimplementasikan penerapan SMAP ISO 37001:2016 pada lingkup keseharian perusahaan, baik pada lingkup perencanaan, pelaksanaan dan evaluasi, komitmen ini disosialisasikan dan wajib diikuti oleh seluruh personel di perusahaan dalam kerangka penguatan sistem manajemen yang disesuaikan untuk membentuk integritas setiap karyawan di perusahaan.

Integritas dijadikan komponen utama untuk mengikat komitmen anti penyuapan seluruh proses aktifitas dalam perusahaan dan menetapkan kebijakan kepatuhan sebagai prasyarat mutlak untuk mencegah praktek suap. Dasar-dasar inilah yang dijadikan pedoman pembuatan perencanaan SMAP untuk mengelola risiko hingga meningkatkan reputasi perusahaan. Perencanaan SMAP dijadikan tolok ukur terhadap implementasi penerapan SMAP dalam proses manajemen bisnis yang dilakukan, dievaluasi secara berkala untuk dikoreksi kelemahannya dan diberikan penguatan agar dapat berkelanjutan.

Perencanaan diaplikasikan oleh perusahaan dalam kebijakan anti suap pada tingkat prosedur penetapan kebijakan, pelaksanaan kebijakan dan pengendalian kebijakan yang mengarah kepada anti penyuapan yang wajar dan proporsional sesuai dengan risiko penyuapan yang dihadapi. Perencanaan pada dasarnya ini tidak menjamin pencegahan risiko penyuapan sepenuhnya, tetapi perencanaan yang dilakukan perusahaan diyakini membantu perusahaan menerapkan rancangan untuk mencegah, mendeteksi dan menanggapi penyuapan.

Rancangan SMAP PT. MMI sebelum pada tahap pelaksanaan telah ditetapkan: (1) identifikasi isu dan stakeholder. Perusahaan menjadikan proses input dan output sebagai kajian dasar untuk menentukan desain dan pemetaan identifikasi isu dan kepentingan stakeholder; (2) perusahaan menilai risiko penyuapan yang terjadi pada potensi isu yang sudah diidentifikasi dan dari penerapan kriteria penyuapan yang telah disusun; (3) penetapan sasaran penerapan SMAP berdasarkan format, kompetensi, kapasitas dan tolok ukur yang sudah ditentukan; (4) keseluruhan kompenen tersebut diatas dirancang pula sebagai rencana materi sosialisasi kepada mitra usaha PT. MMI dalam kerangka memperkenalkan prosedur anti suap dalam kerjasama yang akan dijalin.

2) $D o$

Pelaksanaan atau do dalam penerapan SMAP adalah suatu proses untuk melaksanakan apa yang sudah direncanakan sebelumnya, dimana rancangan SMAP PT. MMI adalah penguatan kebijakan pada tingkat visi, misi, operasional bisnis dan tata kelola manajemen anti 
suap yang menjadikan pimpinan perusahaan sebagai model kepemimpinan yang bersih dan transparan. Dari perencaaan yang telah disusun, PT. MMI melaksanakan rencana yang sudah disusun pada aspek integrity due diligence ke mitra, membuat kontrak/perikatan dengan klausul anti penyuapan, menjalankan pengendalian keuangan dan non-keuangan, melaksanakan sosialisasi terkait SMAP ke Mitra.

Mitra bisnis PT. MMI adalah bagian penting dalam suatu ekosistem bisnis yang perlu disinergikan dalam penerapan SMAP. Oleh karena itu diberlakukan integrity due diligence atau pengujian integritas atas potensi risiko penyuapan yang bakal terjadi dengan : (1) membentuk komitmen anti penyuapan yang sama untuk mencegah penyuapan; (2) mensosialisasikan SMAP sebagai salah satu panduan kerjsama kepada mitra untuk mencegah tawaran suap, penyediaan atau penerimaan hadiah, kemurahan hati, sumbangan dan keuntungan yang layak dianggap sebagai penyuapan. Pelaksanaan integrity due diligence oleh PT. MMI ke mitra mengatur secara detail kebijakan pengendalian gratifikasi.

Prosedur integrity due diligence yang dilakukan adalah : (1) mendorong setiap level dan fungsi serta personil di dalamnya untuk melaporkan kecurigaan atas adanya suatu penyuapan, pelanggaran atau pelemahan SMAP; (2) laporan boleh tanpa nama; (3) laporan akan ditindaklanjuti dengan penyelidikan secara tertutup; (4) perusahaan akan melindungi pelapor; (5) hasil laporan diserahkan kepada orang yang ditugasi untuk mengurus pelanggaran; (6) penyelidikan terhadap kasus suap dapat dikerjasamakan secara investigatif; (7) hasil investigasi dilaporkan kepada fungsi kepatuhan anti penyuapan dan fungsi kepatuhan lainnya; (8) jika hasil investigasi sesuai dengan laporan maka bersifat rahasia; (9) investigasi dilakukan dan dilaporkan kepada personel yang bukan bagian dari peran atau fungsi yang sedang diinvestigasi; (10) detail investigasi dan anti penyuapan diatur dalam Pedoman Sistem Pelaporan Pelanggaran (Whistle Blowing System).

Setelah sosialisasi SMAP kepada mitra bisnis PT. MMI diyakini telah dipahami maka perikatan kerjasama yang akan dilakukan memuat klausul yang berisikan anti penyuapan. Untuk kontrak yang sudah ditandatangani, PT. MMI secara proaktif mengupayakan penyesuaian/ amandemen perjanjian dengan ketentuan klausul terkait anti penyuapan dan apabila terdapat amandemen kontrak yang sudah ditandatangani, maka amandemen harus mencantumkan klausul terkait anti penyuapan.

Klausul anti penyuapan dalam kontrak menjadi persyaratan dalam penerapan SMAP, artinya PT. MMI mesti memberikan perhatian penuh pada aspek ini dan menempatkannya sebagai kebijakan anti penyuapan dan salah satu prosedur yang harus dipenuhi.dalam klausul anti penyuapan. Dalam kontrak kerjsama yang memuat klausul anti penyuapan mengatur tiga hal yang mendasar yakni klausul kepatuhan, klausul right to suspend/terminate, klausul right to audit.

PT. MMI juga menerapkan kebijakan pengendalian keuangan dengan sistem manajemen anti penyuapan. Pengendalian keuangan yang dilakukan meliputi: (1) pemisahan tugas dalam pengecekan, verifikasi, persetujuan untuk proses bisnis yang relevan dengan bidang keuangan, hal ini tercantum dalam SK Kebijakan pengelolaan dana; (2) verifikasi jumlah yang dibayarkan, penerima pembayaran, dokumen pendukung, yang dibutuhkan sesuai kontrak. Selain itu untuk tagihan terkait pengadaan barang jasa, masing-masing juga melakukan verifikasi atas invoice yang ditagihkan sebelum dilakukan pembayaran oleh bagian keuangan; (3) pelaksanaan pengendalian keuangan dan non keuangan membutuhkan lebih dari satu tandatangan pada setiap dokumen.

Dalam perencanaan sosialisasi terkait penerapan SMAP kepada mitra bisnis PT. MMI pada tahap pelaksanaannya adalah menerapkan itikad baik atau keyakinan terhadap pemberian informasi anti suap yang dapat mencegah pelanggaran atau kelemahan dalam sistem 
manajemen anti penyuapan kepada personel yang tepat. Sosialisasi yang dilakukan oleh PT. MMI secara umum adalah pemberian informasi yang hendak memastikan bahwa semua lingkup kerjasama yang dilakukan mengetahui secara pasti prosedur pelaporan, hak, dan perlindungan sesuai prosedur.

\section{3) Check}

Check dalam pendekatan proses SMAP dapat diartikan juga sebagai evaluasi dari perencanaan dan pelaksanaan dari perencanaan yang sudah dilakukan, yakni: melaksanakan integrity due diligence ke Mitra, yakni pengujian integritas kepada mitra usaha dalam kerangka mencegah praktek suap dalam bentuk apapun, membuat kontrak/perikatan dengan klausul anti penyuapan dalam rangka persyaratan dalam penerapan SMAP dan penerapan komitmen untuk pengembangan manajemen ati suap secara berkeanljutan, menjalankan pengendalian keuangan dan non-keuangan yakni pengendalian keuangan yang mengelola risiko penyuapan agar sesuai dengan sistem manajemen anti penyuapan, melaksanakan sosialisasi terkait SMAP ke mitra bisnis PT. MMI

Dalam proses evaluasi, aktivitas yang dilakukan adalah memantau dan mengukur proses, hasil dan layanan yang dihasilkan terhadap kebijakan, tujuan, persyaratan, dan kegiatan yang direncanakan, dan melaporkan hasilnya. Dalam tahap ini, PT. MMI melakukan proses evaluasi dalam kegiatan: proses audit internal SMAP dan melaksanakan tinjauan manajemen.

Audit yang dilakukan secara berkala setiap satu tahun sekali dibuat secara sistematis untuk memastikan bahwa SMAP dilaksanakan dan dipelihara dengan baik, sesuai dengan kebijakan, prosedur, regulasi / perundang-undangan, ISO 37001: 2016. Adapun sistematika audit internal yang dilakukan adalah sebagai berikut: (1) merencanakan, menetapkan, menerapkan dan memelihara program audit, termasuk frekuensi, metode, tanggung jawab, persyaratan perencanaan dan pelaporan, yang harus mempertimbangakan pentingnya proses dimaksud dan hasil dari audit sebelumnya; (2) menentukan kriteria dan lingkup audit untuk setiap audit; (3) memilih auditor yang kompeten dan melasanakan audit untuk memastikan objektivitas dan ketidakberpihakan dari proses audit; (4) memastikan hasil audit dilaporkan pada manajemen yang relevan, fungsi kepatuhan anti penyuapan, manajemen puncak jika sesuai, dewan pengarah (Dewan Komisaris); (5) menyimpan informasi terdokumentasi sebagai bukti penerapan program audit dan hasil audit PT. MMI melakukan audit internal yang wajar, proporsional dan berbasis risiko. Pelaksanaan tinjauan manajemen dilakukan oleh direksi PT. MMI terhadap pelaksanaan SMAP secara berkala sekali dalam satu tahun, untuk memastikan kelanjutan kesesuaian, kecukupan dan keefektifan.

4) Act

Act dalam pendekatan proses dapat diartikan sebagai tindakan yang diambil untuk meningkatkan kinerja. Dalam kaitannya dengan persyaratan pada ISO 37001:2016, tindakan yang diambil perusahaan untuk memperbaiki dan meningkatkan kemampuan manajemen anti supa dilakukan melalui tindakan korektif, yakni tindakan yang diambil ketika terjadi ketidaksesuaian dalam bentuk: (1) pengendalian dan koreksi; (2) pengambilan keputusan atas konsekuensi peristiwa yang terjadi; (3) mengevaluasi kebutuhan untuk tindakan menghilangkan penyebab ketidaksesuaian, agar hal ini tidak terulang kembali atau terjadi ditempat lain melalui peninjauan ketidaksesuaian, menentukan penyebab ketidaksesuaian; (4) menetapkan setiap tindakan yang diperlukan melalui peninjauan keefektifan dari setiap tindakan korektif yang diambil, membuat perubahan terhadap SMAP bila diperlukan.

Tindakan korektif diambil sesuai dengan efek dari ketidaksesuaian yang ditemukan berdasarkan informasi terdokumentasi sebagai bukti dari: (1) sifat ketidaksesuaian dari setiap 
tindakan berikutnya yang diambil; (2) hasil setiap tindakan korektif. Detail aktivitas tercantum dalam prosedur tindakan perbaikan dan peningkatan berkelanjutan perusahaan. Langkah selanjutnya adalah meningkatkan kesesuaian, kecukupan, dan keefektifan SMAP.

\section{Konsep Rancangan SMAP berbasis Manajemen Risiko}

Manajemen risiko digunakan sebagai basis dari penerapan SMAP di PT. MMI. Sistem manajemen risiko PT MMI yang diterapkan mengacu pada ISO 9001:2015, mencakup jenis usaha yang berupa jasa pendidikan dan pelatihan serta jasa pengelolaan dan pengembangan sumber daya manusia. Rancangan manajemen risiko yang ditempuh PT. MMI dimulai dari penetapan komunikasi dan konsultasi.

\section{1) Penetapan Komunikasi dan Konsultasi}

Agar penerapan SMAP berjalan dengan efektif, PT. MMI, mengelola SMAP yang dikomunikasi dan dikonsultasikan secara internal dan eksternal yang relevan dengan manajemen risiko. Penetapan komunikasi dalam manajemen risiko dilakukan dalam lingkup: (1) mengkomunikasikan SMAP berbasis manajemen risiko; (2) melibatkan semua level dan fungsi perusahaan; (4) media komunikasi yang digunakan.

Komunikasi internal yang diselenggarakan PT. MMI adalah sistem komunikasi yang melibatkan seluruh jajaran dan fungsi perusahaan yang dilakukan secara efektif untuk meningkatkan pemahaman dan efektifitas pelaksanaan sistem manajemen risiko. Metode yang digunakan dapat berupa rapat rutin/ meeting, papan pengumuman, publikasi internal, briefing, intranet, email, dan sebagainya. Selain itu perusahaan juga menerapkan matriks komunikasi internal sebagai panduan dasar alur komunikasi.

Komunikasi Eksternal Perusahaan yang dijalankan adalah komunikasi yang berusaha memperdekat hubungan dengan pelanggan dan pihak terkait, sehingga perusahaan memahami harapan dan kebutuhannya. Mekanisme komunikasi dengan pelanggan dan pihak terkait dibangun sesuai etika bisnis yang baik dan saling menguntungkan, sehingga pelanggan dan pihak terkait menjadi puas. Untuk itu perusahaan mensosialisasikan penerapan SMAP berbasis manajemen risiko.

Informasi yang dilakukan didokumentasi, sesuai dengan standar manajemen risiko dan kebutuhan perusahaan. Penyusunan, pelaporan dan pembaharuan laporan komunikasi memuat ketetapan: (1) identifikasi dan deskripsi potensi penyuapan; (2) format pelaporan penyuapan; (3) pendokumentasian pelaporan.

Pengendalian informasi ini dikendalikan untuk memastikan kesesuaiannya untuk menggunakan prosedur dan penanganan srandar anti suap dalam manajemen risiko. Informasi terdokumentasi disimpan sebagai bukti dari potensi atau kecurigaan pelaksanaan suap. Komunikasi sistem manajemen risiko PT. MMI dibagi ke dalam arah yang mencakup: (1) komunikasi internal yang diarahkan untuk mengkonsolidasikan penguatan pelaksanaan manajemen risiko yang dijalankan berdasarkan panduan SMAP; (2) komunikasi yang berorientasi eksternal yang bertujuan mensosialisasikan materi SMAP berbasis manajemen risiko; (3) komunikasi yang dikembangkan untuk menjalankan sistem manajemen risiko dalam semua proses, fungsi dan aktivitas yang berdampak terhadap berkurangnya ketidakpastian akibat suap; (3) pengembangan komunikasi untuk pembangunan manajemen risiko berkelanjutan. Konsultasi kerja yang dilakukan merupakan urutan proses kerja antar lefel dan fungsi yang dijadikan acuan kerja organisasi dalam mencapai penerapan manajemen risiko yang ditetapkan. Berikut Pertanggungjawaban komunikasi yang dibangun dalam manajemen risiko di PT. MMI

\section{2) Penetapan Konteks}

Sebelum ditetapkannya konteks sebagai prasyarat dari penerapan manajemen risiko, pada awalnya perusahaan melakukan perbaikan secara terus menerus, meliputi proses-proses 
bisnis yang ada secara runtut melalui kriteria dan metode serta standar operasional yang dikehendaki dalam penerapannya hingga tingkat pengendalian, pengukuran dan penganalisaan secara berkesinambungan terhadap semua proses. Mengevaluasi kembali implementasi tindakan yang telah diambil untuk memperbaiki proses yang telah berjalan agar bisa sesuai dengan standar ISO 37006:2016.

Setelah itu, penerapan SMAP pada basis manajemen risiko dimulai dari penetapan konteks untuk mendapatkan parameter dasar dalam pengelolaan risiko di lingkungan internal dan eksternal. Konteks adalah suatu pemahaman terhadap konsep lingkungan di mana PT. MMI berusaha mendefinisikan dan mencapai tujuannya melalui penetapan strategi dan upaya pencapaian sasaran organisasi. Dalam penetapan konteks, PT. MMI mendefinisikan sifat dan kompleksitas risiko untuk mengetahui sumber risiko pada kegiatan organisasi dan tujuan organisasi secara keseluruhan.

Penetapan konteks eksternal diarahkan pada analisis pengaruh perubahan lingkungan eksternal yang terdiri dari berbagai faktor, seperti faktor politik, sosial budaya, regulasi, keuangan, lingkungan, hingga kompleksitas jaringan. Adapun penetapan konteks internal diarahkan kepada akselerasi budaya perusahaan, proses dan struktur organisasi kepada pencapaian visi, misi, dan nilai; tata kelola, peran dan akuntabilitas. Cara yang ditempuh PT. MMI dalam melakukan penetapan konteks adalah dengan melakukan review struktur dan bagan organisasi, benchmaking dan self assessment. Sebagaimana persyaratan dalam penerapan SMAP berbasis manajemen risiko sesuai dengan standar SNI ISO 37001:2016 (Djoni et.al., 2020).

\section{3) Identifikasi Risiko}

Penetapan konteks eksternal dan internal PT. MMI yang berkaitan dengan identifikasi risiko adalah bagian yang terpenting dari penerapan manajemen risiko, oleh karena itu, PT. MMI memastikan bahwa analisis yang dilakukan sesuai dengan kebutuhan pelaksanaan SMAP berbasis manajemen risiko. Analisis dilakukan mulai dari penentuan kontrol untuk diterapkan dalam seluruh proses manajemen meliputi: (1) analisis terhadap produk dan jasa dari penyedia eksternal dimaksudkan untuk dimasukkan ke dalam produk dan jasa perusahaan sendiri; (2) analisis terhadap produk dan jasa yang disediakan secara langsung kepada penerima jasa layanan oleh penyedia eksternal atas nama PT. MMI; (3) PT. MMI menganalisis seluruh proses yang disediakan oleh penyedia eksternal sebagai hasil dari keputusan.

PT. MMI juga menganlisis informasi yang terdokumentasi dan setiap tindakan yang telah dan akan diambil untuk memastikan bahwa progres yang dicapai mempengaruhi kemampuan perusahaan yang secara konsisten memberikan dampak positif kepada perusahaan. Analisa yang dilakukan ditekankan kepada ada atau tidaknya dampak potensial yang muncul dari efektivitas kontrol yang diterapkan sistem manajeman risiko terhadap proses, metode, kompetensi, termasuk kualifikasi yang dibutuhkan orang.

Cara-cara yang digunakan dalam evaluasi risiko adalah dengan mengidentifikasi dan kemampuan menelusuri output jaminan kesesuaian produk dan jasa. Hal ini dilakukan dengan persyaratan pemantauan dan pengukuran seluruh produksi dan penyediaan jasa. Hasil evaluasi disiman sebagai informasi dan didokumentasikan. Pada tahap akhir evaluasi dilakukan verifikasi ke rekanan/kolega agar terkomparasi persyaratan kegiatan pasca proses produksi selesai. Sebagai dasar rujukan evaluasi digunakan persyaratan hukum dan peraturan, konsekuensi yang tidak diinginkan potensial yang terkait dengan produk dan jasa, persyaratan pengguna jasa alih daya, pendidikan dan pelatihan, umpan balik pengguna jasa alih daya.

Selanjutnya dilakukan pencatatan dan pelaporan sebagai hasil dari pemantauan, pengukuran, analisis dan evaluasi dari management representative terhadap seluruh staf dari bagian yang berpengaruh langsung terhadap sistem manajemen risiko yang berpedoman kepada 
SMAP serta membuat perencanaan dan melaksanakannya. Oleh karena itu pencatatan dan pelaporan berisikan hasil pekerjaan operasional, pencatatan manajemen mutu, kesesuaian peraturan perundangan yang berlaku, perubahan atau perbaiakan yang dilakukan, efektifitas manajemen risiko. Pelaporan dan pencatatan dikontrol langsung oleh management representative guna menetukan tindak lanjut serta langkah perbaikan selanjutnya.

Bila dalam pencatatan dan pelaporan yang dibuat belum tercapai suatu hal yang diinginkan atau diharapkan maka pencatatan atas tindakan koreksi dan pencegahannya harus harus dilaporkan kembali. Kepuasan pengguna jasa layanan PT. MMI juga dilaporkan dalam kerangka memantau persepsi mereka terhadap kebutuhan dan harapan mereka.

Terakhir, pemantauan dilakukan untuk memverifikasi kepatuhan penuh dari proses bisnis secara internal maupun rekan bisnis yang tidak dikendalikan terhadap persyaratan untuk mengambil langkah yang wajar untuk meyakinkan dalam bentuk review bahwa risiko penyuapan dapat dipantau, dilaporkan dan diaudit. Hasil pematauan dan review dapat dilaporkan kepada manajemen puncak. Pemantauan yang dilakukan oleh PT. MMI mencakup pemantauan terhadap sistem manajemen anti penyuapan yang mencakup efektifitas pelaksanaannya, efektifitas pengendaliannya, efektifitas pertanggungjawabannya dan efektifitas mengatasi kepatuhan terhadap kegagalan yang sebelumnya teridentifikasi. Review dilakukan untuk mendapatkan gambaran terhadap adanya ketidakpatuhan, ketika persyaratan anti peyuapan tidak terpenuhi dan ketika sasaran tidak tercapai.

\section{Penilaian SMAP ISO 37001:2016 Berbasis Manajemen Risiko di PT. MMI}

SMAP ISO 37001:2016 bersifat fleksibel, dapat berdiri sendiri atau dapat diintegrasikan dengan sistem manajemen lainnya. PT. MMI mengintegrasikannya dengan sistem manajemen risiko. Pengintegrasian SMAP 37001:2016 berbasis manajemen risiko menjadi antibribery management systems requirements with guidance for use buat perusahaan, diterapkan berdasarkan sepuluh klausul yang dipersyaratkan, yaitu:

\section{1) Lingkup}

Pada klausul ini, PT. MMI menjabarkan persyaratan dan panduan SMAP ISO 37001:2016 untuk menetapkan, menerapkan, memelihara, meninjau, dan meningkatkan sistem manajemen anti penyuapan yang sudah berjalan sebelumnya. Sistem Manajemen Anti Penyuapan (ISO 37001:2016) yang diterapkan digabungkan dengan Sistem Manajemen risiko untuk memandu proses manajemen anti suap menjadi sebuah standar untuk mendeteksi dan menangani penyuapan.

\section{2) Acuan Normatif}

Acuan normatif penerapan sistem manajemen anti penyuapan adalah standar ISO 37001:2016 dan manajemen risiko sebagai dasar dari pengintegrasiannya.

\section{3) Istilah dan Definisi}

Istilah dan definisi untuk menjalankan manajemen anti suap ditetapkan oleh PT. MMI dalam rangka memperjelas batasan dan pemahaman serta upaya pencapaian ISO 37001:2016 berbasis manajemen risiko, dimana istilah dan definisi yang ditetapkan diantaranya adalah : (1) penyuapan adalah menawarkan, menjanjikan, memberikan, menerima, atau meminta keuntungan yang tidak semestinya dari nilai apapun (berupa keuangan atau non keuangan), langsung atau tidak langsung, terlepas dari lokasi, merupakan pelanggaran peraturan perundang-undangan, sebagai bujukan atau hadiah untuk orang yang bertindak atau menahan diri dari bertindak terkait kinerja dari tugas orang tersebut; (2) pihak berkepentingan pemangku kepentingan adalah orang atau perusahaan rekanan yang dapat mempengaruhi, dipengaruhi, atau menganggap dirinya terpengaruh oleh suatu keputusan atau aktivitas; fungsi kepatuhan anti penyuapan adalah orang (kelompok) dengan tanggung jawab dan wewenang untuk melaksanakan operasi sistem manajemen anti penyuapan. 
Klausul 1 sampai dengan 3 di atas bukan persyaratan utama dalam penerapan SMAP karena hanya menyangkut lingkup standar, acuan normatif, istilah dan definisi. Adapun klausul yang merupakan persyaratan penerapan yang harus diperhatikan dan dipenuhi adalah:

\section{4) Konteks Perusahaan}

Seperti yang sudah dibahas di atas, pemahaman konteks yang dibangun oleh PT. MMI dalam klausul ini adalah untuk mengukur rancangan SMAP berbasis manajemen risiko dengan pemahaman yang paling mendasar dari perusahaan yakni kebutuhan, harapan, penilaian dan sistem anti suap dengan struktur, fungsi dan kewenangan dalam pencegahannya.

\section{5) Kepemimpinan}

Dewan Komisaris PT. MMI menyetujui kebijakan anti penyuapan dan berkomitmen memastikan penerapan strategi anti penyuapan dengan sumber daya yang cukup dan tepat dalam melaksanakan pengawasan yang wajar terhadap penerapan dan keefektifan SMAP berbasis manajemen risiko oleh Direksi.

Sedangkan Direksi PT. MMI memastikan kebijakan dan sasaran ditetapkan, diterapkan, dipelihara, dan ditinjau secara cukup untuk mengatasi risiko penyuapan pada perusahaan dengan memastikan integrasi persyaratan SMAP kedalam proses perusahaan.

Kepemimpinan Dewan Komisaris dan Dewan Direksi dijadikan contoh dalam penerapan integritas kepada seluruh karyawan untuk tidak melakukan penyuapan dan patuh kepada aturan yang ditetapkan.

\section{6) Perencanaan}

Perencanaan yang dilakukan PT. MMI dalam klausul ini adalah mengintegrasikan proses SMAP dengan perusahaan agar dapat mencegah atau mengurangi pengaruh yang tidak diinginkan yang relevan dengan kebijakan dan sasaran anti penyuapan melalui efektifitas penerapan SMAP berbasis manajemen risiko secara berkelanjutan.

\section{7) Dukungan}

PT. MMI memberikan dukungan berupa penyediaan sumber daya yang diperlukan untuk penetapan, penerapan, pemeliharaan dan peningkatan berkelanjutan dari sistem manajemen anti penyuapan yang berkompeten, bertanggungjawab, peduli dan disertakan dalam berbagai pelatihan untuk membina kemampuannya.

8) Operasi

Dalam tahapan ini,PT MMI melakukan hal-hal yang dianggap signifikan dalam menerapkan SMAP ISO 37001:2016 berbasis manajemen risiko dengan melakukan: (1) pengendalian operasi, terdiri dari penetapan kinerja, mengendalikan proses sesuai kriteria, mengkomunikasikan setiap jangkauan dalam proses yang ditetapkan; (2) membangun proses komunikasi pada setiap level dan fungsi di setiap proses produksi; (3) melakukan proses control eksternal, menetapkan dan menerapkan kriteria untuk evaluasi, seleksi, monitoring kinerja, dan evaluasi ulang penyedia eksternal, berdasarkan kemampuan mereka untuk memberikan proses atau produk dan jasa sesuai dengan kebutuhan perusahaan.

9) Evaluasi Kinerja

Mengevaluasi setiap efektifitas dari setiap tindakan yang diambil untuk mengatasi risiko dan peluang proporsional terhadap potensial akibat atas ketidaksesuaian produk dan jasa.

\section{0) Peningkatan}

Peningkatan dilakukan untuk melakukan pembenahan dengan cara talent mapping dan job opening untuk menggali lebih dalam potensi dan kompetensi karyawan agar dapat melakukan penempatan karyawan yang sesuai antara potensi dan kompetensi dengan posisi 
dalam perusahaan. Pembenahan ini diarahkan kepada penyelenggaraan manajemen anti penyuapan berdasarkan ISO 37001:2016 berdasarkan manajemen risiko.

Kesepuluh klausul dalam penerapan SMAP ISO 37001:2016 di atas telah dipenuhi oleh PT. MMI. Sistem ini menurut Susanti et.al. (2018) pemberlakuannya di Indonesia masih bersifat sukarela (voluntary). Hal inilah yang melatarbelakangi pengendalian utama dari sistem ini, terutama pada fungsi sekretariat manajemen mutu tidak secara spesifik menempatkan personel pada level dan fungsinya sesuai dengan jobdes tanpa rangkap jabatan, sesuai kapasitas dan kompetensi yang dikehendaki dalam panduan SMAP ISO 37001:2016 berbasis manajemen risiko.

PT. MMI hingga saat ini belum menemukan satu kasuspun dari potensi dan kejadian kasus suap. Hal ini bukan berarti tidak terdapat kasus penyuapan karena informasi tervalidasi yang menyajikan bukti empirik mengenai pengaruh atau implikasi implementasi SMAP pada pencegahan praktik suap di PT. MMI belum komprehensif. Begitu pula dengan informasi mengenai persepsi mitra bisnisnya. Pengaruh SMAP berbasis manajemen risiko secara komprehensif perlu diketahui lebih lanjut pada tataran implementasinya. Menurut Lukiawan (2018), SMAP akan lebih efektif pada tataran implementatif tanpa ketergantungan dari holding dalam penerapan kebijakan zona integritas di lingkungan perusahaan sendiri dengan tiga sasaran, yaitu mewujudkan manajemen anti suap dan terjadinya proses efektif, efisien, produktif.

Penanggulangan risiko dilakukan dengan memastikan dijalaninya standar dan kebijakan yang dijalankan secara konsisten untuk memastikan efektifitas pengendalian baik internal maupun eksternal. Monitoring perlu dilaksanakan secara regular dengan melibatkan tim kepatuhan. Pada bagian review, proses yang disajikan adalah evaluasi pemantauan, pengukuran, analisis, audit internal, tinjauan manajemen dan tinjauan fungsi kepatuhan. Hal ini dilakukan untuk menjaga kualitas SMAP yang diterapkan.

Pencatatan dan pelaporan dilakukan atas proses kelayakan, pengendalian keuangan, pengendalian non keunagan, pengendalian pihak ketiga, pengendalian area risiko tinggi, pelaporan kepedulian, dan investigasi penanganan yang sudah dilakukan. Keuangan dan Operasional (KDO) merupakan karyawan PT. MMI yang bertanggungjawab dalam proses pencatatan, pengadministrasian, pengarsipan, verifikasi dokumen keuangan dan atau pembiayaan serta penginputan transaksi keuangan di Kantor Pusat. Pencatatan dan pelaporan memberikan kontribusi mereka terhadap efektivitas SMAP, termasuk manfaat dari peningkatan kinerja anti- penyuapan dan pelaporan dugaan penyuapan.

\section{PENUTUP}

\section{Simpulan}

Suap adalah salah satu perilaku korupsi yang saat ini menjadi salah satu persoalan mendasar kelembagaan baik pemerintah dan non pemerintah. Perilaku ini dapat berdampak pada rusaknya tatanan organisasi dan upaya strategis pencapaian sasaran dan tujuan organisasi. Fenomena umum ini disadari oleh PT. MMI dapat pula terjadi dan berpotensi terjadi dalam perusahaan. Oleh karena itu sejak awal sebelum mengadopsi SMAP ISO 37001:2016 berbasis manajemen risiko PT. MMI telah menerapkan metode anti suap berbasis manajemen mutu sepanjang tahun 2020.

PT. MMI memperoleh ISO 37001:2016 pada bulan April 2021. Kebijakan yang diambil pimpinan perusahaan untuk mengadopsi sistem anti penyuapan ini diputuskan berdasarkan dua pertimbangan: (1) SMAP 37001:2016 adalah sistem manajemen anti suap yang diakui dan digunakan secara luas di dunia internasional untuk mengantisipasi praktek suap dalam suatu sistem komunikasi yang handal dan memposisikan pemimpin sebagai role model agar tercipta 
kompetisi yang sehat untuk mencapai tujuan perusahaan; (2) PT. MMI merupakan salah satu perusahaan grup BUMN yang diwajibkan memperoleh sertifikat ISO 37001SMAP berdasarkan Surat Meneg BUMN No.S-35/MBU/02/2020. Penerapan SMAP diintegrasikan dengan sistem manajemen risiko, menggantikan sistem penjaminan mutu yang sebelumnya digunakan.

Sejak diterapkan SMAP ISO 37001:2016 berbasis manajemen risiko, belum ditemukan satu kasus suap pun yang terjadi. Hanya ada satu keluhan pada bulan Maret 2021. Keluhan ini telah dicatat dalam logbook complaint dan sudah ditindaklanjuti. Indikasi ini menjelaskan bahwa secara konsepsional dan operasional PT. MMI telah mempersiapkan perencanaan, pelaksanaan dan evaluasi sistem ini dengan baik, termasuk 10 klausul persyaratan SMAP yang harus dilaksanakan, yakni klausul 4 sampai dengan klausul 10.

Saran

Perlunya penerapan, pelaksanaan dan pengendalian ISO SMAP 37001:2016 berbasis manajemen risiko antara PT. MMI dengan perusahaan holding secara terpisah agar didapat tolok ukur yang tepat dalam penetapan sasaran penerapan SMAP di PT. MMI. Penerapan prasyarat penempatan personil sebaiknya berdasarkan pada kompetensi yang dibutuhkan pada masing-masing fungsi dan level tanpa rangkap jabatan pada organ strategis. Kedua hal diatas hanya dapat dilakukan dengan menerapkan komunikasi dan konsultasi yang optimal kepada BOD perusahaan, dimana kekurangan dalam penerapan SMAP di PT. MMI bermula dari lemahnya konsultasi dan komunikasi yang terjadi secara internal.

\section{DAFTAR PUSTAKA}

Andreas, N. M., (2017). Suap di Sektor Privat: Dapatkah Dijerat?, Jurnal Integritas, 3(1), 53 85.

Denzin, Norman, K., Yvonna, S. L., (2009). Handbook of Qualitative Research. Yogyakarta: Pustaka Pelajar.

Djoni, S., Sri, W., Deni, S., (2020). Kitab Anti Suap, Cara Mudah Menerapkan Sistem Manajemen Anti Penyuapan (SMAP) Berbasis SNI ISO 37001:2016. Diakses 11 Agustus 2021, pukul 21.20 WIB dari https://cpb.solutions

Gilang, M. Husein., and Radiant, V. I., (2015). Analisis Manajemen Resiko Teknologi Informasi Penerapan Pada Document Management System di PT. Jabar Telematika (JATEL). Jurnal Teknik Informatika dan Sistem Informasi, 1(2).

Kusumah, M. W., (2001). Tegaknya Supremasi Hukum. Bandung: PT. Remaja Rosdakarya.

Lokobal, A., Sumajouw, M. D. J., Sompie, B.F., (2014). Manajemen Risiko Pada Perusahaan Jasa Pelaksana Konstruksi di Propinsi Papua (Study Kasus di Kabupaten Sarmi). Jurnal Ilmiah Media Engineering, 4(2), 109-118.

Lukiawan, R., (2018). Kesiapan Organisasi dalam Implementasi Standar ISO 37001 (Studi Kasus di UD. X dan Dinas Y). Jurnal Standardisasi, 20(2), 159-169.

Mapuasari, S. A., and Mahmudah, H., (2018). Korupsi Berjamaah: Konsensus Sosial atas Gratifikasi dan Suap, Jurnal Integritas, 4(2), 159-176.

Moleong, L.J., (2013). Metode Penelitian Kualitatif. Edisi Revisi. Bandung: PT. Remaja Rosdakarya.

Mudrika, B. S., Salsabila, D. K., Mualif, Z. J., (2020). Analisis Manajemen Resiko Bisnis (Studi pada Cuanki Asoy Jember). Jurnal Akuntansi Universitas Jember, 18(1), 51-61.

Nur, K. I., Ubud, S. D., Jumilah, H., Nur, S., (2012). Manajemen Resiko Berbasis Spiritual Islam. Ekuitas: Jurnal Ekonomi dan Keuangan, 16(2), 184-208.

Pitoyo, A. J., Aditya, B., Amri, I., Rokhim, A. A., (2021). Impacts and Strategies Behind COVID-19-Induced Economic Crisis: Evidence from Informal Economy. The Indian Journal of Labour Economics, 64, 641-661. 


\section{JURNALKU}

Volume 2 No. 1, 2022

\section{(c) (†) (?)}

Prabowo, H. Y., and Suhernita, (2018). Be Like Water: Developing A Fluid Corruption Prevention Strategy. Journal of Financial Crime, 25(4), 997-1023.

Ratih, A. S., Rahmi, Y., Debrina, P., (2017). Analisa Manajemen Risiko Pada Industri Kecil Rotan Di Kota Malang. Journal of Industrial Engineering Management, 2(2), 39-47.

Robert, J. C., (2006). Simple Tools and Techniques for Enterprise Risk Management. New York: John Wiley \& Sons Ltd.

Susanti, D. S., Sarah, N., Hilmi, N., (2018). Korporasi Indonesia Melawan Korupsi: Strategi Pencegahan. Jurnal Integritas, 4(2): 207- 232. 